Dubravko Murgić*

Majda Rijavec ${ }^{* * *}$

Dubravka Miljković ${ }^{* * *}$
JEL Classification J24, J28, M50, D91

Izvorni znanstveni rad

https://doi.org/10.32910/ep.70.1.1

\title{
INICIJALNA VALIDACIJA SKRAĆENOG UPITNIKA PSIHOLOŠKOG KAPITALA (UPK-12) NA HRVATSKOM UZORKU
}

Psihološki kapital (PsiKap) relativno je novi konstrukt koji se definira kao pozitivno psihološko stanje razvoja pojedinca, a uključuje četiri pozitivne psihološke komponente: samoefikasnost, optimizam, nadu i psihološku otpornost. Brojna istraživanja pokazala su njegovu povezanost s mnogim pozitivnim organizacijskim ishodima. U Hrvatskoj do danas nije provedeno nijedno istraživanje pouzdanosti $i$ valjanosti postojećih instrumenta za mjerenje PsiKapa. Stoga je cilj ovog rada bio ispitati pouzdanost $i$ valjanost skraćenog Upitnika PsiKapa s 12 čestica (UPK-12). U istraživanju su sudjelovala 304 zaposlenika različitog roda, dobi i pozicije u jednoj organizaciji. Konfirmatornom faktorskom analizom potvrđeno je postojanje jednog zajedničkog faktora višeg reda koji je nadređen i predstavlja četiri navedene pod-dimenzije. Unutarnja je pouzdanost skale zadovoljavajuća. Potvrđena je pozitivna povezanost između PsiKapa i poslovnog i životnog zadovoljstva, a rukovoditelji su pokazali višu razinu PsiKapa od zaposlenika. Dobiveni rezultati ukazuju da skraćena verzija upitnika PsiKapa pokazuje zadovoljavajuću pouzdanost $i$ valjanost.

* D. Murgić, struč. spec. oec., asistent na Katedri za poduzetništvo i menadžment, Veleučilište VERN (E-mail: dubravkomurgich@hotmail.com).

${ }^{* *}$ Dr. sc. M. Rijavec, redovita profesorica, Učiteljski fakultet Sveučilišta u Zagrebu (E-mail: majda.rijavec@ufzg.hr).

**** Dr. sc. D. Miljković, redovita profesorica, Učiteljski fakultet Sveučilišta u Zagrebu (Email:dubravka.miljkovic@ufzg.hr).

Rad je primljen u uredništvo 12.03.2018. godine, a prihvacen je za objavu 11.10.2018. 
Ključne riječi: psihološki kapital (PsiKap), samoefikasnost, optimizam, nada, psihološka otpornost, psihometrijska validacija, Upitnik psihološkog kapitala s 12 čestica (UPK-12)

\section{Uvod}

"Što ne možeš mjeriti, ne možeš ni upravljati."

Peter Drucker

Svjedočimo velikim tehnološkim, socioekonomskim, demografskim, geopolitičkim i ekološkim promjenama koje drastično mijenjaju uvjete i način poslovanja i života ljudi, okoliš i prostor (Jurčić, 2016; World Economic Forum, 2016). Za uspješnu prilagodbu tim promjenama i izazovima sadašnjosti i budućnosti, ljudi, organizacije, industrije, gospodarstva i društva trebaju i odgovarajuće pozitivne psihološke resurse, uz ostale resurse (ekonomski, ljudski i socijalni kapital) i sposobnosti (radnu sposobnost pojedinca, operativne i dinamičke sposobnosti organizacija, održivu društvenu proizvodnju i potrošnju itd.).

Istraživanje pozitivnih psiholoških resursa znatno se povećalo pojavom pozitivne psihologije početkom ovog stoljeća (Rijavec i Miljković, 2009). Tada su Seligman i Czikszentmihalyi (2000) ukazali na to da je psihologija u velikoj mjeri bila usmjerena na istraživanje negativnih fenomena u okviru modela mentalnih bolesti, dok su zanemareni pozitivni fenomeni koji omogućuju pojedincima i zajednici da napreduju. Nakon toga proveden je velik broj istraživanja koja su bila usmjerena na optimalno ljudsko funkcioniranje. Kad je u pitanju područje menadžmenta i ponašanja u organizaciji, razvilo se nekoliko pravaca istraživanja i praktičnih pristupa koji su primjenjivali pozitivnu psihologiju na radnom mjestu (Luthans i Avolio 2009; Luthans, Youssef-Morgan i Avolio, 2015). Među njima ističe se škola Pozitivnog organizacijskog ponašanja (engl. Positive organizational behavior - POB) koja se definira kao "istraživanje i primjena pozitivnih ljudskih snaga i psiholoških kapaciteta koji se mogu mjeriti, razvijati i efikasno njima upravljati s ciljem povećanja radnog učinka" (Luthans, 2002, str. 59). Kako bi se napravila razlika u odnosu na druge i teorijske i praktične pozitivne pristupe, definirani su kriteriji za uključivanje konstrukata u pozitivno organizacijsko ponašanje. Ti konstrukti moraju biti pozitivni, utemeljeni na teoriji i istraživanjima, moguće ih je mjeriti i razvijati, te su povezani s poželjnim stavovima i ponašanjima, a posebno s učinkom na radnom mjestu (Luthans, 2002; Luthans, Youssef i Avolio, 2007b; Luthans i sur, 2015).

U okviru POB-a istraživani su različiti psihološki konstrukti, a za četiri se pokazalo da najbolje odgovaraju postavljenim kriterijima, a to su: samoefikasnost, 
optimizam, nada i psihološka otpornost. Samoefikasnost je vjerovanje osobe da sa svojim vještinama, odnosno kompetencijama, može ostvariti neki cilj; optimizam uključuje opće očekivanje pozitivnih ishoda i pozitivne atribucije uspjeha; nada se odnosi na ustrajanje u ostvarivanju ciljeva (i, po potrebi, modifikaciju putova koji do njih vode), dok je psihološka otpornost mogućnost oporavka, čak i psihološkog napredovanja nakon doživljenog neuspjeha (Luthans i sur., 2007b). U zadnjih desetak godina posebna pozornost posvećena je sinergiji ovih osobina u okviru jednog konstrukta pod nazivom psihološki kapital (PsiKap) koji se definira kao pozitivno psihološko stanje razvoja osobe koje uključuje četiri navedene psihološke varijable.

U Hrvatskoj je do danas objavljeno svega nekoliko članaka o PsiKapu (Murgić, 2014; Murgić, 2016; Rijavec i Miljković, 2009), ali nije objavljeno nijedno istraživanje pouzdanosti i valjanosti nekog od postojećih instrumenta PsiKapa. Stoga je glavni cilj ovog rada bio provjeriti pouzdanost i valjanost kraće verzije Upitnika PsiKapa s 12 čestica - UPK-12 (engl. Psychological Capital Questionnaire with 12 items - PCQ-12; Avey, Avolio i Luthans, 2011a; Cesaro, 2016; Luthans, Avey, Clapp-Smith i Li, 2008) na hrvatskom uzorku.

\section{Pregled literature}

PsiKap se pokazao povezanim s mnogim pozitivnim organizacijskim ishodima kao što su radni učinak - bez obzira radi li se o samoprocjenama zaposlenika (Avey, Reichard, Luthans, i Mhatre, 2011b; Rego, Marques, Leal, Sousa i Cunha, 2010) ili procjenama njihovih menadžera (Luthans, Avey, Avolio i Peterson, 2010; Peterson, Luthans, Avolio, Walumbwa i Zhang, 2011). Meta-analiza koja je uključivala 51 istraživanje (Avey i sur., 2011b) pokazala je pozitivnu povezanost između PsiKapa i zadovoljstva poslom, dobrobiti i lojalnosti organizaciji te negativnu povezanost sa stresom na poslu, anksioznošću, cinizmom i namjerom napuštanja tvrtke. Zanimljivo je pritom da ni ovdje nisu dobivene razlike s obzirom na način mjerenja ovih varijabli (procjene od strane drugih, samoprocjene ili objektivni pokazatelji). Osim pozitivnih ishoda na individualnoj razini pokazalo se da je kolektivni PsiKap povezan i s boljom timskom učinkovitošću (Peterson i Zhang, 2011; Walumbwa, Luthans, Avey i Oke, 2011).

Osim pozitivnih ishoda na individualnoj i kolektivnoj razini, neka istraživanja pokušala su odrediti i antecedente psihološkog kapitala, tj. kako i zašto osoba dostiže i održava određenu razinu psihološkog kapitala. Tako je istraživanje koje je proveo Avey (2014) pokazalo da su individualne razlike (poput samopoštovanja i proaktivnosti) najvažniji prediktor psihološkog kapitala, slijedi način rukovođenja i karakteristike posla, dok demografske varijable nisu imale znatnu ulogu. 
Najčešće korišten instrument za mjerenje PsiKapa je Upitnik PsiKapa koji se sastoji od 24 tvrdnje (PCQ-24). U istraživanjima je pokazao zadovoljavajuću faktorsku strukturu s četiri varijable kao faktorima prvog reda i PsiKapom kao faktorom drugog reda (Luthans, Avolio, Avey i Norman, 2007a). Najveći broj istraživanja PsiKapa koristio je upravo ovaj upitnik (Avey i sur., 2011b; Newman, Ucbasaran, Zhu i Hirst, 2014). U novije vrijeme pojavila se i skraćena verzija Upitnika PsiKapa s 12 tvrdnji (PCQ-12) koja je validirana u nekoliko država (Avey i sur., 2011a), ali ne i u Hrvatskoj.

Na temelju prethodno navedenih rezultata validacije Upitnika PsiKapa postavljena je prva hipoteza.

H1: Očekuje se potvrda PsiKapa kao jednog zajedničkog faktora višeg reda koji je nadređen i predstavlja četiri pod-dimenzije (samoefikasnost, optimizam, nadu i psihološka otpornost), kao i zadovoljavajuća unutarnja pouzdanost upitnika PsiKapa i na hrvatskom uzorku.

Osim konstruktne valjanosti bit će provjerena i konvergentna valjanost pomoću korelacije s varijablama koje bi teorijski trebale biti povezane s psihološkim kapitalom, a to su zadovoljstvo poslom i zadovoljstvo životom.

Luthans i suradnici (2007a, str. 550) navode da psihološki kapital predstavlja dispoziciju osobe koja se odražava "kroz pozitivnu procjenu okolnosti i vjerojatnosti uspjeha temeljenoj na motivaciji za ulaganje truda i upornosti". Stoga se može očekivati da će zaposlenici s visokom razinom psihološkog kapitala općenito imati pozitivniji stav prema svom poslu, a time i biti njime zadovoljniji. Veći broj istraživanja ispitivao je ulogu psihološkog kapitala u zadovoljstvu poslom zaposlenika (npr., Avey, Luthans i Youssef, 2010). Neki autori (Avey i sur., 2011b) vezu između PsiKapa i zadovoljstva poslom objašnjavaju time što optimisti općenito očekuju veći uspjeh na poslu, a zbog samoefikasnosti više vjeruju u svoje sposobnosti, što ih onda čini i zadovoljnijima na poslu. Samoefikasnost također pridonosi tome da su uporniji, lakše prihvaćaju izazove i ulažu više napora u ostvarivanje svojih ciljeva, dok im nada omogućuje da vide više mogućih puteva do cilja i tako se lakše suoče s preprekama. Osim toga, PsiKap je povezan s radnim učinkom (Avey i sur., 2010; Rego i sur., 2010; Walumbwa i sur., 2011) u različitim kontekstima. Ovaj povećani učinak dovodi do toga da su zaposlenici pozitivnije raspoloženi i imaju više resursa za suočavanje sa svakodnevnim izazovima na poslu. To povećava i njihovo samopouzdanje, očekivanje uspjeha i motivaciju, a time i njihovo zadovoljstvo poslom.

Također se može očekivati da će PsiKap biti pozitivno povezan sa zadovoljstvom životom kao komponentom dobrobiti, jer su istraživanja pokazala da su komponente PsiKapa povezane sa životnim zadovoljstvom (Lucas, Diener i Suh, 1996), pa se može očekivati i da ukupni PsiKap bude pozitivno povezan sa život- 
nim zadovoljstvom. Youssef-Morgan i Luthans (2015) predložili su konceptualni okvir koji povezuje psihološki kapital i dobrobit. Prema ovom okviru PsiKap olakšava pozitivnu kognitivnu procjenu događaja u prošlosti, sadašnjosti i budućnosti. Dobrobit se temelji na zadovoljstvu u različitim životnim domenama, a pokazalo se da je PsiKap povezan sa zadovoljstvom poslom, zdravljem, odnosima i životom općenito. Dobrobit je manje pod utjecajem objektivnih životnih događaja, a više pod utjecajem selektivnog pamćenja tih događaja, a PsiKap olakšava procese nužne za interpretaciju i zadržavanje pozitivnih konstruktivnih sjećanja koji su važni za dobrobit. I na kraju, PsiKap utječe na razvoj pozitivnih afektivnih stanja koja su važna u suočavanju s kriznim trenucima u životu.

$\mathrm{Na}$ temelju navedenih rezultata postavljena je druga hipoteza istraživanja.

\section{H2: Očekuje se pozitivna povezanost PsiKapa sa zadovoljstvom poslom $i$ zadovoljstvom životom.}

Istraživanja Luthansa i suradnika (2007a) pokazala su da četiri navedena faktora PsiKapa tvore konstrukt višega reda koji je bolji prediktor radnog učinka i zadovoljstva poslom nego njegovi pojedini dijelovi, što znači da faktori PsiKapa imaju sinergijsku vrijednost koja konstruktu PsiKapa daje dodatnu vrijednost. Na temelju takvih rezultata postavljena je sljedeća hipoteza.

H3: Očekuje se da će ukupni PsiKap u većoj mjeri pridonositi poslovnom $i$ životnom zadovoljstvom nego svaka komponenta (samoefikasnost, nada, otpornost i optimizam) zasebno.

Također, kao dodatna mjera valjanosti, provjerene su razlike između zaposlenika i rukovoditelja jer neka dosadašnja istraživanja ukazuju da rukovoditelji imaju veću razinu PsiKapa od ostalih zaposlenika (Cenciotti, Alessandri i Borgogni, 2016).

Napredovanje na poslu ovisi o sposobnostima zaposlenika da unaprijede svoju učinkovitost. Oni koji su u tome uspješniji, koriste različita konkretna ponašanja (preoblikovanje posla ili engl. job crafting) kako bi stvorili bolje radne uvjete i razvili svoje kompetencije (Tims i Bakker, 2010). Što pritom u većoj mjeri koriste svoj PsiKap, to je veća vjerojatnost da će biti unaprijeđeni. Istraživanja pokazuju da ispitanici koji svoje psihološke resurse poput PsiKapa izražavaju kroz različita pozitivna organizacijska ponašanja, imaju veću šansu dobiti promaknuće (npr. Peterson i sur., 2011). Jedno je istraživanje također pokazalo da su zaposlenici s višom razinom PsiKapa skloniji preoblikovanju posla što je onda povezano i s njihovim promaknućem (Cenciotti i sur., 2016). Rezultati mnogih istraživanja također pokazuju pozitivnu povezanost između zadovoljstva poslom i visine prihoda (npr. Bakan i Buyukbese, 2013; Mabaso i Dlamini, 2017). Budući da su viša primanja u pravilu povezana s višim položajem u organizacijskoj hijerarhiji, za očekivati je 
višu razinu PsiKapa kod rukovoditelja. Na temelju ovih rezultata postavljena je četvrta hipoteza.

H4: Rukovoditelji će imati višu razinu psihološkog kapitala od ostalih zaposlenika

Kao što je već navedeno, glavni je cilj ovoga istraživanja provjera pouzdanosti i valjanosti kraće verzije Upitnika PsiKapa s 12 na hrvatskom uzorku. Pritom su analizirani faktorska struktura i pouzdanost upitnika, povezanost PsiKapa i poslovnog i životnog zadovoljstva kao indikacija konvergentne valjanosti te razlike između rukovoditelja i ostalih zaposlenika u PsiKapu kao dodatna mjera valjanosti.

\section{Metoda}

\subsection{Sudionici}

U istraživanju su sudjelovala 304 ispitanika koji su zaposleni u jednoj banci u Zagrebu (od toga 74\% žena i 26\% muškaraca), prosječno stari 41 godinu ( $M=40.85$; $\mathrm{SD}=8.77$ ). Rukovoditelja je bilo 33\%, a ostalih zaposlenika 67\%. Među rukovoditeljima je najviše bilo onih na nižoj razini rukovođenja (79\%), potom onih na srednjoj razini rukovođenja (15\%), a najmanje onih na visokoj razini rukovođenja (6\%). Polovina sudionika (50\%) imala je završenu srednju školu, a najmanje ih je imalo završeno manje od 4 godine srednje škole ili gimnazije (1\%). Ostali zaposlenici imali su završen stručni studij u trajanju kraćem od tri godine (4\%), stručni studij u trajanju od najmanje tri godine (8\%), specijalistički diplomski stručni studij koji traje jednu do dvije godine (13\%), preddiplomski sveučilišni studij koji u pravilu traje tri do četiri godine (5\%), preddiplomski i diplomski sveučilišni studij ili integrirani preddiplomski i diplomski sveučilišni studij (16\%) te poslijediplomski specijalistički studij u trajanju od jedne do dvije godine (3\%).

\subsection{Instrumenti}

Upitnik demografskih podataka sadrži pitanja za prikupljanje podatka o rodu, dobi, razini obrazovanja, položaju u organizaciji, veličini i glavnoj djelatnosti organizacije.

Upitnik psihološkog kapitala - UPK-12 (engl. Psychological Capital Questionnaire with 12 items - PCQ-12; Avey i sur., 2011a; Cesaro, 2016; Luthans 
i sur., 2008a) skraćena je verzija upitnika PsiKapa s 24 čestice - UPK-24 (engl. Psychological Capital Questionnaire with 24 items - PCQ-24; Luthans i sur., 2007b). Upitnik se sastoji od četiri subskale koje mjere nadu (4 tvrdnje, primjerice: Kada bih se našao u problemima na poslu, znam da bih pronašao više načina kako da se iz njih izvučem), optimizam (2 tvrdnje, Kada je moj posao u pitanju, uvijek gledam pozitivnu stranu), samoefikasnost (3 tvrdnje, Siguran sam u sebe kad trebam predstaviti svoje područje rada na sastancima s upravom) i otpornost (3 tvrdnje, Sa stresnim događajima na poslu obično dobro izlazim na kraj). Tvrdnje se procjenjuju na Likertovoj skali od šest stupnjeva (od 1 - uopće se ne slažem do 6 - u potpunosti se slažem). Originalni upitnik pripremljen je za upotrebu postupkom dvostrukog povratnog prevođenja.

Skala zadovoljstva životom (engl. The Satisfaction with Life Scale; Diener, Emmons, Larsen i Griffin, 1985) skala je od 5 tvrdnji za kognitivnu procjenu subjektivne dobrobiti. Tvrdnje se procjenjuju na Likertovoj skali od 5 stupnjeva (od 1 - uopće se ne slažem do 5 - u potpunosti se slažem).

Opće zadovoljstvo poslom mjereno je jednom tvrdnjom: Općenito gledajući, zadovoljan/na sam svojim poslom (Scarpello i Campbell, 1983), koju su ispitanici procjenjivali na Likertovoj skali od 5 stupnjeva (od uopće se ne odnosi na mene do u potpunosti se odnosi na mene).

\subsection{Postupak}

Podaci su prikupljeni putem mrežnog portala tako da je voditelj odjela ljudskih resursa zamoljen da informira zaposlenike i potakne ih da ispune upitnik. Istraživanje je bilo dobrovoljno i anonimno. Upitnik je na portalu bio dostupan mjesec dana.

\subsection{Statistička analiza}

Statistička obrada podataka provedena je statističkim programima SPSS 21 i AMOS 21.

Za provjeru faktorske strukture Upitnika PsiKapa korištena je konfirmatorska faktorska analiza. Za procjenu pristajanja modela korišteni su kriteriji koje su predložili Hu i Bentler (1999). To su vrijednosti relativnog hi-kvadrata između 2 i 5, standardizirana prosječna kvadratna kovarijanca reziduala (RMSEA) $\leq 0.06$, komparativni indeks pristajanja (CFI) $\geq 0.95$ i Tucker-Lewis-index (TLI) $\geq 0.95$. 
Za određivanje povezanosti između PsiKapa i poslovnog i životnog zadovoljstva korišten je Pearsonov koeficijent korelacije.

\section{Rezultati}

\subsection{Deskriptivni podaci}

U tablici 1. prikazane su interkorelacije među ispitivanim varijablama, deskriptivni podaci (aritmetičke sredine, standardne devijacije, asimetričnost i spljoštenost distribucija te stvarni i mogući raspon rezultata) i Cronbachovi $\alpha$ koeficijenti unutarnje pouzdanosti.

\section{Tablica 1 .}

INTERKORELACIJE, DESKRIPTIVNI POKAZATELJI I KOEFICIJENTI UNUTARNJE POUZDANOSTI MJERENIH VARIJABLI

\begin{tabular}{|l|c|c|c|c|c|c|c|}
\hline \multicolumn{7}{|c|}{ Interkorelacije } \\
\hline & 1. & 2. & 3. & 4. & 5. & 6. & 7. \\
\hline 1. Samoefikasnost & - & & & & & & \\
\hline 2. Nada & $.58^{* *}$ & - & & & & & \\
\hline 3. Otpornost & $.50^{* *}$ & $.55^{* *}$ & - & & & & \\
\hline 4. Optimizam & $.24^{* *}$ & $.43^{* *}$ & $.30^{* *}$ & - & & & \\
\hline 5. PsiKap & $.76^{* *}$ & $.86^{* *}$ & $.74^{* *}$ & $.55^{* *}$ & & & \\
\hline 6. Zadovoljstvo poslom & $.19^{* *}$ & $.31^{* *}$ & $.22^{* *}$ & $.34^{* *}$ & $.40^{* *}$ & - & \\
\hline 7. Zadovoljstvo životom & $.17^{* *}$ & $.37^{* *}$ & $.24^{* *}$ & $.43^{* *}$ & $.46^{* *}$ & $.52^{* *}$ & - \\
\hline \multicolumn{7}{|c|}{ Deskriptivni pokazatelji } & \\
\hline Aritmetička sredina & 4.89 & 4.71 & 5.06 & 4.54 & 4.83 & 3.83 & 3.74 \\
\hline Standardna devijacija & 0.78 & 0.71 & 0.64 & 0.98 & 0.61 & 1.04 & 0.89 \\
\hline Asimetričnost & -0.97 & -0.91 & -0.59 & -0.85 & -1.81 & -0.93 & -0.77 \\
\hline Spljoštenost & 1.99 & 2.74 & .26 & 0.69 & 2.70 & 0.56 & 0.30 \\
\hline Stvarni raspon & $1-6$ & $1-6$ & $3.33-6$ & $1-5$ & 1.58 & $1-5$ & $1-5$ \\
\hline Mogući raspon & $1-6$ & $1-6$ & $1-6$ & $1-6$ & $1-6$ & $1-5$ & $1-5$ \\
\hline Cronbachov $\alpha$ & .77 & .73 & .68 & .63 & .87 & n.p. & .89 \\
\hline
\end{tabular}

Napomena: n.p. - nije primjenjivo, skala s jednom česticom. ${ }^{*} \mathrm{p}<.05$, ${ }^{*} \mathrm{p}<.01$. 
Iz tablice 1. vidljivo je da sudionici istraživanja imaju iznadprosječne rezultate na svim subskalama PsiKapa kao i na ukupnom rezultatu PsiKapa. Teorijski prosjek iznosi 3.5, a sve prosječne vrijednosti su iznad 4.5. Pritom je najviši rezultat na skali otpornosti, a najmanji na skali optimizma. Ovi rezultati u skladu su s rezultatima dobivenim u istraživanjima u drugim državama (Gibson i Hicks, 2018; León-Pérez, Antino i León-Rubio, 2016).

Interkorelacije između četiri podskale UPK-12 bile su pozitivne i značajne i kretale su se između $\mathrm{r}=.31$ i .58 . Također, korelacije sve četiri podskale PsiKapa, kao i ukupni PsiKap bili su značajno pozitivno povezani s procjenama zadovoljstva poslom i zadovoljstva životom.

Koeficijenti unutarnje pouzdanosti bili su nešto niži nego što se navodi u literaturi (između .75 i .87: Azanza, Domínguez, Moriano i Molero, 2014; Luthans i sur., 2007a), ali još uvijek prihvatljivi. Uobičajeno se vrijednosti između .70 i .80 smatraju prihvatljivima, iako Kline (2000) navodi kako se koeficijenti unutarnje konzistencije manji od .70 mogu smatrati prihvatljivima za neke konstrukte u psihologiji.

Kako su se rodne razlike pokazale samo u dvije komponente PsiKapa ali ne i u ukupnom PsiKapu, a povezanost između dobi i komponenti PsiKapa i ukupnog PsiKapa je bila neznačajna ili vrlo nisko značajna, konfirmatorna faktorska analiza provedena je na cijelom uzorku.

\subsection{Faktorska valjanost Upitnika psihološkog kapitala s 12 čestica (UPK-12)}

Kako bismo potvrdili faktorsku strukturu višeg reda upitnika PsiKapa, proveli smo konfirmatornu faktorsku analizu (CFA). U prvom koraku provedena je konfirmatorna faktorska analiza u kojoj je svaka dimenzija PsiKapa bila povezana s pripadajućim tvrdnjama i istovremeno s faktorom višeg reda, psihološkim kapitalom. Ovaj model pokazao je zadovoljavajuće pristajanje. Nakon toga provjerili smo još tri alternativna modela: jednofaktorski model, model koreliranih faktora prvog reda i model nekoreliranih faktora prvog reda. Rezultati su prikazani u tablici 2. 
Tablica 2.

\section{INDEKSI PRISTAJANJA ZA RAZLIČITE MODELE ZA UPITNIK PSIKAPA S 12 ČESTICA}

\begin{tabular}{|l|c|c|c|c|c|c|c|}
\hline Alternativni modeli & $\chi^{2}$ & $d f$ & $p$ & $\chi^{2} / d f$ & CFI & TLI & RMSEA \\
\hline Model drugog reda & 91.17 & 50 & .000 & 1.82 & .96 & .95 & .05 \\
\hline 1-faktorski model & 224.23 & 54 & .000 & 1.15 & .85 & .81 & .11 \\
\hline $\begin{array}{l}\text { Model koreliranih faktora } \\
\text { prvog reda }\end{array}$ & 110.91 & 48 & .000 & 2.31 & .94 & .92 & .07 \\
\hline $\begin{array}{l}\text { Model nekoreliranih } \\
\text { faktora prvog reda }\end{array}$ & 525,64 & 54 & .000 & 9,73 & .61 & .53 & .17 \\
\hline
\end{tabular}

Napomena: $\chi^{2}$, hi kvadrat; df, broj stupnjeva slobode; CFI, comparative fit index; TLI, Tucker-Lewis index; RMSEA, standardizirana prosječna kvadratna kovarijanca reziduala.

Rezultati pokazuju da jednofaktorski model i model nekoreliranih faktora prvog reda nemaju značajne indekse pristajanja. Četverofaktorski model s PsiKapom kao faktorom drugog reda ima najbolje indekse pristajanja, a rezultati pokazuju da je pristajanje bolje nego za model koreliranih faktora prvog reda $\left(\Delta \chi^{2}=19.74\right.$, $p<.001)$. Time je potvrđena hipoteza 1 .

\subsection{Psihološki kapital, poslovno i životno zadovoljstvo}

Razlika u PsiKapu između muškaraca i žena nije bila značajna ( $\mathrm{t}=1.47, \mathrm{p}=.15)$, a korelacija između PsiKapa i dobi bila je značajna, ali vrlo niska $(r=.16, p<.001)$. Dvije hijerarhijske regresijske analize u kojima su kao prediktori u prvom koraku uneseni dob, rod i psihološki kapital, a u drugom interakcije roda i PsiKapa te dobi i PsiKapa, pokazale su da rod i dob ne moderiraju odnos između PsiKapa kao prediktorske varijable i poslovnog i životnog zadovoljstva kao kriterijskih varijabli. Stoga se o povezanosti između PsiKapa i životnog i poslovnog zadovoljstva zaključilo na temelju Pearsonovih koeficijenata korelacije. Korelacija između PsiKapa sa zadovoljstvom poslom iznosila je $\mathrm{r}=.40(\mathrm{p}<.01)$ kao i sa zadovoljstvom životom $\mathrm{r}=.46(\mathrm{p}<.01)$. Ovim je potvrđena druga hipoteza da će PsiKap biti značajno pozitivno povezan s ove dvije varijable. 


\subsection{Analiza korisnosti}

Za provjeru 3. hipoteze korišten je pristup koji su predložili Judge i suradnici (Erez i Judge, 2001; Judge, Erez, Bono i Thoresen, 2003). Provedena je analiza korisnosti kako bi se provjerilo doprinosi li ukupni PsiKap varijanci poslovnog i životnog zadovoljstva više od pojedinačnih komponenti. Rezultati ove analize prikazani su u tablici 5.

Doprinos ukupnog rezultata na upitniku PsiKapa uspoređen je s doprinosom rezultata na svakoj pojedinoj dimenziji.

Tablica 3.

\section{REZULTATI ANALIZE KORISNOSTI}

\begin{tabular}{|l|c|c|}
\hline & Zadovoljstvo poslom & Zadovoljstvo životom \\
\hline Samoefikasnost & $.03^{* *}$ & $.03^{* *}$ \\
\hline PsiKap & $.25^{* * *}$ & $.15^{* * *}$ \\
\hline PsiKap & $.21^{* * *}$ & $.16^{* * *}$ \\
\hline Samoefikasnost & $.07^{* * *}$ & $.03^{* *}$ \\
\hline Nada & $.14^{* * *}$ & $.10^{* * *}$ \\
\hline PsiKap & $.07^{* * *}$ & $.06^{* * *}$ \\
\hline PsiKap & $.21^{* * *}$ & $.16^{* * *}$ \\
\hline Nada & $>.01$ & $>.01$ \\
\hline Otpornost & $.06^{* * *}$ & $.05^{* * *}$ \\
\hline PsiKap & $.18^{* * *}$ & $.12^{* * *}$ \\
\hline PsiKap & $.21^{* * *}$ & $.16^{* * *}$ \\
\hline Otpornost & $.02^{* *}$ & $.01^{*}$ \\
\hline Optimizam & $.18^{* * *}$ & $.12^{* * *}$ \\
\hline PsiKap & $.07^{* * *}$ & $.06^{* * *}$ \\
\hline PsiKap & $.21^{* * *}$ & $.16^{* * *}$ \\
\hline Optimizam & $.05^{* * *}$ & $.02^{* *}$ \\
\hline
\end{tabular}

Napomena: U tablici su prikazani koeficijenti multiple korelacije u prvom koraku, a u drugom promjene u koeficijentima multiple korelacije; ${ }^{*} \mathrm{p}<.05 ; * * \mathrm{p}<.01 ; * * * \mathrm{p}<.001$.

U analizi je u regresijsku jednadžbu svaki put prvo unesena pojedinačna komponenta PsiKapa, kako bi se vidjelo koliko doprinosi objašnjenju poslovnog i životnog zadovoljstva. Nakon toga u regresijsku jednadžbu unesen je rezultat ukupnog PsiKapa, kako bi s provjerilo doprinosi li on dodatno objašnjenju kriterijskih 
varijabli. Ovi su rezultati nakon toga uspoređeni s obrnutom situacijom, kad je u regresijsku jednadžbu prvo unesen ukupni PsiKap, a onda pojedina komponenta. Kao što se vidi iz tablice 3., doprinos ukupnog PsiKapa objašnjenju varijance zadovoljstva poslom i životom uvijek je veći od doprinosa svake komponente posebno. Primjerice, kad se kontrolira samoefikasnost, PsiKap doprinosi čak dodatnih 25\% varijance zadovoljstva poslom, a kad se kontrolira PsiKap, samoefikasnost pridonosi samo 7\%. Slično je i s ostalim pojedinačnim komponentama. Ovim je potvrđena hipoteza 3.

\subsection{Razlike između rukovoditelja i ostalih zaposlenika}

Za dodatnu indikaciju valjanosti upitnika poslužila nam je i razlika u psihološkom kapitalu između rukovoditelja i zaposlenika. Razlike u ispitivanim varijablama između zaposlenika i rukovoditelja prikazane su u tablici 4.

Tablica 4 .

RAZLIKE IZMEĐU ZAPOSLENIKA I RUKOVODITELJA U ISPITIVANIM VARIJABLAMA

\begin{tabular}{|l|c|c|c|c|c|c|c|}
\hline & \multicolumn{2}{|c|}{$\begin{array}{c}\text { Zaposlenici } \\
(\mathbf{N = 2 0 5})\end{array}$} & \multicolumn{2}{|c|}{$\begin{array}{c}\text { Rukovoditelji } \\
(\mathbf{N = 9 9})\end{array}$} & \multicolumn{2}{|l|}{} \\
\hline & $\mathbf{M}$ & SD & $\mathbf{M}$ & SD & $\mathbf{t}$ (df=282) & $\boldsymbol{p}$ & Cohen d \\
\hline Samoefikasnost & 4.80 & 0.79 & 5.07 & 0.72 & 2.87 & .004 & .35 \\
\hline Nada & 4.68 & 0.73 & 4.77 & 0.68 & 1.07 & .284 & .14 \\
\hline Otpornost & 4.99 & 0.67 & 5.20 & 0.54 & 2.79 & .006 & .34 \\
\hline Optimizam & 4,45 & 1.03 & 4.71 & 0.85 & 2.26 & .003 & .28 \\
\hline PsiKap & 4.76 & 0.63 & 4.97 & 0.55 & 2.94 & .004 & .36 \\
\hline Zadovoljstvo poslom & 3.73 & 1.13 & 4.02 & 0.82 & 2.53 & .024 & .19 \\
\hline Zadovoljstvo životom & 3.70 & 0.96 & 3.85 & 0.69 & 1.64 & .141 & .29 \\
\hline
\end{tabular}

Napomena: broj sudionika za ovu analizu je manji jer neki nisu naznačili svoj status u organizaciji.

Razlika između zaposlenika koji nisu na rukovodećim položajima i onih koji su rukovoditelji pojavila se u tri komponente PsiKapa, varijablama samoefikasnosti, psihološke otpornosti, optimizma, kao i u ukupnom psihološkom kapitalu. U svim navedenim varijablama rukovoditelji su imali više rezultate od zaposlenika, 
a veličina učinka kreće se od male do umjerene. Rukovoditelji su također bili zadovoljniji svojim poslom, dok nije bilo razlika u zadovoljstvu životom.

\section{Rasprava}

U okviru teorijskih modela u području pozitivne psihologije (Peterson i Seligman, 2004; Seligman, Steen, Park i Peterson, 2005) i pozitivnog organizacijskog ponašanja (Luthans i sur., 2007a; Nelson i Cooper, 2007) identificirani su različiti novi pozitivni konstrukti, među kojima je i konstrukt PsiKapa. PsiKap pokazao se vrlo korisnim za objašnjenje različitih pozitivnih ishoda u organizacijama, uključujući radni učinak, dobrobit i zdravlje. Stoga je cilj ovog rada bio validirati hrvatsku kraću verziju Upitnika PsiKapa s 12 tvrdnji (UPK-12). Rezultati ovog istraživanja daju potvrdu inicijalne valjanosti hrvatske verzije ovog upitnika jer pokazuju prihvatljivu unutarnju pouzdanost kao i zadovoljavajuću faktorsku strukturu drugog reda.

Dodatna analiza korisnosti pokazala je da ukupni PsiKap doprinosi poslovnom i životnom zadovoljstvu više nego svaka pojedinačna dimenzija posebno. Time je ponovno potvrđena temeljna teorijska postavka autora ovog koncepta (Luthans i sur., 2007a) da se radi o ključnom pozitivnom faktoru višeg reda čiji su indikatori već poznati konstrukti samoefikasnosti, nade, optimizma i otpornosti. Također, hijerarhijske regresijske analize pokazale su da je nakon kontrole varijabli roda i statusa u organizaciji (zaposlenici/rukovoditelji) PsiKap značajno doprinosio objašnjenju varijance i poslovnog i životnog zadovoljstva.

Kao što je i očekivano, rukovoditelji su pokazali više rezultate u ukupnom psihološkom kapitalu i u tri pojedinačne komponente PsiKapa. Iako nisu bile glavni problemi istraživanja, u ovom radu su kontrolirane i rodne i dobne razlike u psihološkom kapitalu. Rodne razlike pojavile su se samo u dvije komponente PsiKapa, a povezanost između dobi i PsiKapa bila je niska. To je u skladu s dosadašnjim istraživanjima koja pokazuju nisku povezanost između različitih sociodemografskih karakteristika i PsiKapa (Avey, 2014; Luthans i sur., 2007a).

Glavna je prednost ovoga istraživanja u tome što su sudionici bili zaposleni i razlikovali su se po većem broju sociodemografskih obilježja. Naime, veliki broj dosadašnjih istraživanja PsiKapa proveden je na studentima. No, bez obzira na to što je na sudionicima ovog istraživanja potvrđena faktorska struktura upitnika, za konačnu validaciju potrebno je provesti provjeru na zaposlenicima koji su zaposleni u različitim organizacijama (kao što su, primjerice javna poduzeća, neprofitne organizacije, škole i druge ustanove), žive u različitim regijama u Hrvatskoj i imaju različitu vrstu obrazovanja. Također, u istraživanja bi trebalo uključiti više 
varijabli, poput radnog učinka, zaokupljenosti poslom, ali i negativnih indikatora dobrobiti, poput stresa, sagorijevanja na poslu i fizičkog zdravlja.

Znatno je ograničenje i to što se radi o kros-sekcijskom, korelacijskom istraživanju koje ne omogućuje određivanje uzroka i posljedica. Također, zbog zajedničke varijance metode, povezanost između varijabli može biti umjetno povećana pa bi se u budućnosti trebalo provesti longitudinalno istraživanje koje bi pokazalo moguće razlike između ispitivanih varijabli.

Nadalje, radi se o istraživanju u kojem su sudionici sami odlučivali hoće li posjetiti mrežnu stranicu i ispuniti upitnik. Na tu odluku mogli su utjecati različiti faktori kao što su, primjerice, trenutno zadovoljstvo životom i poslom ili interes za predmet istraživanja. Moguće je da sudionici koji su izrazito nezadovoljni životom ili poslom nisu ni željeli ispunjavati upitnik ili su sudionici s višim PsiKapom bili skloniji ispuniti upitnik. Iako istraživanja pokazuju da i mjere dobrobiti koje se ispunjavaju na internetu imaju zadovoljavajuću pouzdanost i valjanost (Howell, Rodzon, Kurai i Sanchez, 2010), rezultate bi trebalo provjeriti i klasičnom metodom tipa papir-olovka.

I dosadašnja istraživanja pokazala su jasnu pozitivnu vezu između PsiKapa i zadovoljstva poslom (Larson i Luthans, 2006) što je od posebne važnosti jer se zadovoljstvo poslom u mnogim istraživanjima pokazalo pozitivno povezanim $\mathrm{s}$ radnim učinkom (npr. Judge i sur., 2003). Prema očekivanju, PsiKap se pokazao povezan i sa životnim zadovoljstvom. Dosadašnja istraživanja pokazala su da zaposlenici s nižom razinom PsiKapa pokazuju i veću razinu neravnoteže između poslovnog i privatnog života i manji osjećaj smisla života što može dovesti i do nižeg zadovoljstva životom (Newman i sur., 2014). To je za organizacije također od iznimne važnosti jer istraživanja pokazuju da su zadovoljniji radnici i uspješniji na poslu (Zelenski, Murphy i Jenkins, 2008; Wright, Cropanzano i Bonett, 2007).

U pozitivnoj psihologiji postoje i pokušaji tzv. pozitivnih intervencija koje služe za povećanje pozitivnih resursa na razini pojedinca, grupe ili zajednice (Rijavec, 2016). I u području PsiKapa osim teorijskih istraživanja postoje i pokušaji mikrointervencija za njegovo povećanje u različitim kontekstima. Tako su Luthans, Avey, Avolio, Norman i Combs (2006) razvili jednu mikro intervenciju za povećanje PsiKapa u obliku trosatne radionice u kojoj se utječe na razvoj svake od pojedinih dimenzija. Tako se nada razvija na način da se ljudima pomaže da prihvate strategije približavanja, a ne izbjegavanja te da kroz postavljanje ciljeva postanu pragmatičniji. Samoefikasnost se potiče na tri načina: postavljanjem ciljeva i vizualizacijom uspješnog ostvarenja tih ciljeva; razmjenom ciljeva i sugestijama za njihovo ostvarenje i pozitivnim povratnim informacijama od strane voditelja i sudionika radionice. Aktivnost u kojoj sudionici vizualiziraju moguće prepreke na putu do cilja, a onda pokušavaju mentalno izmijeniti takve okolnosti služi razvoju psihološke otpornosti, dok se tehnika samo-govora koja služi pro- 
mjeni negativnih misli koristi za povećanje optimizma. Ova intervencija dovela je ne samo do povećanja PsiKapa nego i do znatne financijske dobiti. Kasnija istraživanja potvrdila su efikasnost ove intervencije s drugim voditeljima i dugoročnijim efektima (Dello Russo i Stoykova, 2015).

\section{Zaključak}

Bez obzira na navedene nedostatke može se zaključiti da skraćena verzija upitnika PsiKapa pokazuje zadovoljavajuću pouzdanosti i valjanost i može se koristiti u daljem istraživanjima ovog konstrukta i u evaluaciji eventualnih praktičnih intervencija. Nastavak istraživanja trebao bi ići u smjeru longitudinalnih istraživanja kako bi se provjerilo jesu li zaposlenici s višom razinom samoefikasnosti, optimizma, nade i psihološke otpornosti, u odnosu na one s nižom razinom PsiKapa, uspješniji u dinamičnom, globalnom okruženju s kojim se danas suočava većina poslovnih subjekata.

"Premda je kontinuirano ulaganje u financijski, ljudski i socijalni kapital nužno, u ovakvom okruženju to prestaje biti dovoljno" (Luthans i sur., 2007a, str. 568).

\section{Literatura:}

Avey, J. B. (2014). The left side of psychological capital: New evidence on the antecedents of PsyCap. Journal of Leadership and Organizational Studies, 21(2), 141-149. Dostupno na https://doi.org/10.1177/1548051813515516

Avey, J. B., Avolio, B. J. i Luthans, F. (2011a). Experimentally analyzing the impact of leader positivity on follower positivity and performance. The Leadership Quarterly, 22(2), 282-294. Dostupno na https://doi.org/10.1016/j.leaqua.2011.02.004

Avey, J. B., Luthans, F. i Youssef, C. M. (2010). The additive value of positive psychological capital in predicting work attitudes and behaviors. Journal of Management, 36(2), 430-452. Dostupno na https://doi.org/10.1177/0149206308329961

Avey, J. B., Reichard, R. J., Luthans, F. i Mhatre, K. H. (2011b). Meta-analysis of the impact of positive psychological capital on employee attitudes, behaviors, and performance. Human Resource Development Quarterly, 22(2), 127-152. Dostupno na https://doi.org/10.1002/hrdq.20070

Azanza, G., Domínguez, A., Moriano, J. A. i Molero, F. (2014). Capital psicológico positivo: Validación del cuestionario PCQ en España. Anales de Psicología, 30(1), 294301. Dostupno na https://doi.org/10.6018/analesps.30.1.153631 
Bakan, I. i Buyukbese, T. (2013). The relationship between employees' income level and employee job satisfaction: An empirical study. International Journal of Business and Social Science, 4(7), 18-25. Dostupno na http://ijbssnet.com/journals/Vol_4_No_7_ July_2013/3.pdf

Cenciotti, R., Alessandri, G. i Borgogni, L. (2016). Psychological capital and career success over time: The mediating role of job crafting. Journal of Leadership \& Organizational Studies, 24 (3), 372-384. Dostupno na https://doi.org/10.1177/1548051816680558

Cesaro, R. J. (2016). Psychological capital as a mediator between team cohesion and productivity (Doctoral dissertation). Minneapolis: Walden University. Dostupno na http://scholarworks.waldenu.edu/cgi/viewcontent.cgi?article=3355\&context=dissert ations

Dello Russo, S. i Stoykova, P. (2015). Psychological capital intervention (PCI): A replication and extension. Human Resource Development Quarterly, 26(3), 329-347. Dostupno na https://doi.org/10.1002/hrdq.21212

Diener, E., Emmons, R. A., Larsen, R. J. i Griffin, S. (1985). The satisfaction with life scale. Journal of Personality Assessment, 49(1), 71-75. Dostupno na https://doi. org/10.1207/s15327752jpa4901_13

Erez, A. i Judge, T. A. (2001). Relationship of core self-evaluations to goal setting, motivation, and performance. Journal of Applied Psychology, 86(6), 1270-1279. Dostupno na https://doi.org/10.1037/0021-9010.86.6.1270

Gibson, A. i Hicks, R. E. (2018). Psychological capital and core self-evaluations in the workplace: Impacts on well-being, International Journal of Psychological Studies, (10)2, 15-24. Dostupno na https://doi.org/10.5539/ijps.v10n2p15

Howell, R. T., Rodzon, K. S., Kurai, M. i Sanchez, H. (2010). A validation of well-being and happiness surveys for administration via the Internet. Behavior Research Methods, 42(3), 775-784. Dostupno na: https://doi.org/10.3758/BRM.42.3.775.

Hu, L. i Bentler, P. M. (1999). Cutoff criteria for fit indexes in covariance structure analysis: Conventional criteria versus new alternatives. Structural Equation Modeling: A Multidisciplinary Journal, 6(1), 1-55. Dostupno na https://doi. org/10.1080/10705519909540118

Judge, T. A., Erez, A., Bono, J. E. i Thoresen, C. J. (2003). The core self-evaluations scale: Development of a measure. Personnel Psychology, 56(2), 303-331. Dostupno na https://doi.org/10.1111/j.1744-6570.2003.tb00152.x

Jurčić, Lj. (2016). Hrvatsko gospodarstvo i svjetsko okruženje. Ekonomski pregled, 67(6), 605-638. Dostupno na http://www.hde.hr/sadrzaj.aspx?Podrucje=1458

Kline, P. (2000). The handbook of psychological testing, Second edition. London: Routledge. Dostupno na https://www.routledge.com/Handbook-of-PsychologicalTesting-2nd-Edition/Kline/p/book/9780415211581

Larson, M. i Luthans, F. (2006). Potential added value of psychological capital in predicting work attitudes. Journal of Leadership \& Organizational Studies, 13(2), 75-92. Dostupno na https://doi.org/10.1177/10717919070130020601 
León-Pérez, J. M., Antino, M. i León-Rubio, J. M. (2016). Adaptation of the short version of the Psychological Capital Questionnaire (PCQ-12) into Spanish. Revista de Psicología Social, 32(1), 196-213. Dostupno na https://doi.org/10.1080/02134748.20 16.1248024

Lucas, R. E., Diener, E. i Suh, E. (1996). Discriminant validity of well-being measures. Journal of Personality and Social Psychology, 71(3), 616-628. Dostupno na https:// doi.org/10.1037/0022-3514.71.3.616

Luthans, F. (2002). Positive organizational behavior: Developing and managing psychological strengths. Academy of Management Perspectives, 16(1), 57-75. Dostupno na https://doi.org/10.5465/ame.2002.6640181

Luthans, F. i Avolio, B. J. (2009). The "point" of positive organizational behavior. Journal of Organizational Behavior, 30(2), 291-307. Dostupno na https://doi.org/10.1002/ job.589

Luthans, F., Avey, J. B., Avolio, B. J., Norman, S. M. i Combs, G. J. (2006). Psychological capital development: Toward a micro-intervention. Journal of Organizational Behavior, 27(3), 387-393. Dostupno na https://doi.org/10.1002/job.373

Luthans, F., Avey, J. B., Avolio, B. J. i Peterson, S. J. (2010). The development and resulting performance impact of positive psychological capital. Human Resource Development Quarterly, 21(1), 41-67. Dostupno na https://doi.org/10.1002/hrdq.20034

Luthans, F., Avey, J. B., Clapp-Smith, R. i Li, W. (2008). More evidence on the value of Chinese workers' psychological capital: A potentially unlimited competitive resource? The International Journal of Human Resource Management, 19(5), 818-827. Dostupno na https://doi.org/10.1080/09585190801991194

Luthans, F., Avolio, B. J., Avey, J. B. i Norman, S. M. (2007a). Positive psychological capital: Measurement and relationship with performance and satisfaction. Personnel Psychology, 60(3), 541-572. Dostupno na https://doi.org/10.1111/j.17446570.2007.00083.x

Luthans, F., Youssef, C. M. i Avolio B. J. (2007b). Psychological capital: Developing the human competitive edge. New York: Oxford University Press. Dostupno na https:// doi.org/10.1093/acprof:oso/9780195187526.001.0001

Luthans, F., Youssef-Morgan, C. M. i Avolio, B. J. (2015). Psychological capital and beyond. New York: Oxford University Press. Dostupno na https:/global.oup.com/academic/ product/psychological-capital-and-beyond-9780199316472?q=Psychological\%20capita1\%20and\%20beyond\&lang=en\&cc=hr

Mabaso, C. M. i Dlamini, B. I. (2017). Impact of compensation and benefits on job satisfaction. Research Journal of Business Management, 11(2), 80-90. Dostupno na https://doi.org/10.3923/rjbm.2017.80.90

Murgić, D. (2014). Psihološki kapital kao čimbenik konkurentnosti, rasta i zaposlenosti u malom gospodarstvu u Hrvatskoj i Europskoj uniji. Ekonomska misao i praksa, 23(1), 277-290. Dostupno na https://hrcak.srce.hr/index.php?show=clanak\&id_clanak_jezik=182468 
Murgić, D. (2016.). Psihološki kapital kao čimbenik inovativnosti gospodarstva. Ekonomska misao i praksa, 25(1), 177-196. Dostupno na https://hrcak.srce.hr/index. php?show=clanak\&id_clanak_jezik=236049

Nelson, D. i Cooper, C. L. (2007). Positive organizational behavior: Accentuating the positive at work. London: SAGE Publications Ltd. Dostupno na https://doi. org/10.4135/9781446212752

Newman, A., Ucbasaran, D., Zhu, F. i Hirst, G. (2014). Psychological capital: A review and synthesis. Journal of Organizational Behavior, 35(1), 120-138. Dostupno na https:// doi.org/10.1002/job.1916

Peterson, C. i Seligman, M. E. P. (2004). Character strengths and virtues: A handbook and classification. New York: Oxford University Press and Washington, DC: American Psychological Association. Dostupno na http://www.apa.org/pubs/books/4317046. aspx

Peterson, S. J., Luthans, F., Avolio, B. J., Walumbwa, F. i Zhang, Z. (2011). Psychological capital and employee performance: A latent growth modeling approach. Personnel Psychology, 64(2), 427-450. Dostupno na https://doi.org/10.1111/j.17446570.2011.01215.x

Peterson, S. J. i Zhang, Z. (2011). Examining the relationships between top management team psychological characteristics, transformational leadership, and business unit performance. U M. A. Carpenter (Ur.), The Handbook of research on Top Management Teams (str. 127-149). Cheltenham, UK: Edward Elgar Publishing Ltd. Dostupno na https://www.e-elgar.com/shop/the-handbook-of-research-on-top-management-teams?___website=uk_warehouse

Rego, A., Marques, C., Leal, S., Sousa, F. i Cunha, M. P. (2010). Psychological capital and performance of Portuguese civil servants: exploring neutralizers in the context of an appraisal system. The International Journal of Human Resource Management, 21(9), 1531-1552. Dostupno na https://doi.org/10.1080/09585192.2010.488459

Rijavec, M. (2016). Self help and positive psychology: Can happiness be learned? U Z. Marković, M. Đurišić Bojanović i G. Đigić, (Ur.), Individual and Environment: International Thematic Proceedia (str. 15-21). Niš, University of Niš, Faculty of Philosophy. Dostupno na http://bib.irb.hr/prikazi-rad?\&lang=enMikac\&rad=865049

Rijavec, M. i Miljković, D. (2009). Pozitivna psihologija na poslu. Zagreb: IEP-D2. Dostupno na http://www.iep.hr/nasa-izdanja-2/pozitivna-psihologija-na-poslu-192/

Scarpello, V. i Campbell, J. P. (1983). Job satisfaction: Are all the parts there? Personnel Psychology, 36(3), 577-600. Dostupno na https://doi.org/10.1111/j.1744-6570.1983. tb02236.x

Seligman, M. E. i Csikszentmihalyi, M. (2000). Positive psychology: An introduction. American Psychologist, 55(1), 5-14. Dostupno na https://doi.org/10.1037/0003066X.55.1.5

Seligman, M. E., Steen, T. A., Park, N. i Peterson, C. (2005). Positive psychology progress: Empirical validation of interventions. American Psychology, 60(5), 410-421. Dostupno na https://doi.org/10.1037/0003-066X.60.5.410 
Tims, M. i Bakker, A. B. (2010). Job crafting: Towards a new model of individual job redesign. South African Journal of Industrial Psychology, 36(2), 1-9. Dostupno na https://doi.org/10.4102/sajip.v36i2.841

Walumbwa, F. O., Luthans, F., Avey, J. B. i Oke, A. (2011). Authentically leading groups: The mediating role of collective psychological capital and trust. Journal of Organizational Behavior, 32(1), 4-24. Dostupno na https://doi.org/10.1002/job.653

World Economic Forum (2016). The Future of Jobs Report. Geneva: World Economic Forum. Dostupno na http://www3.weforum.org/docs/WEF_Future_of_Jobs.pdf

Wright, T. A., Cropanzano, R. i Bonett, D. G. (2007). The moderating role of employee positive well-being on the relation between job satisfaction and job performance. Journal of Occupational Health Psychology, 12(2), 93-104. Dostupno na https://doi. org/10.1037/1076-8998.12.2.93

Youssef-Morgan, C. M. i Luthan, F. (2015). Psychological capital and well-being. Stress \& Health, 31(3), 180-188. Dostupno na https://doi.org/10.1002/smi.2623

Zelenski, J. M., Murphy, S. A. i Jenkins, D. A. (2008). The happy-productive worker thesis revisited. Journal of Happiness Studies, 9(4), 521-537. Dostupno na https://doi. org/10.1007/s10902-008-9087-4

\section{INITIAL VALIDATION OF THE SHORTENED PSYCHOLOGICAL CAPITAL QUESTIONNAIRE (PCQ-12) ON CROATIAN SAMPLE}

\section{Summary}

Psychological capital (PsyCap) is a relatively new construct, defined as an individual's positive psychological state of development, and includes four positive psychological components: selfefficacy, optimism, hope and psychological resiliency. Numerous studies have shown its correlation with many positive organizational outcomes. Until today, no reliability and validity study of the existing instruments for measuring PsyCap has been conducted in Croatia. Therefore, the aim of this paper was to examine the reliability and validity of the shortened PsyCap Questionnaire with 12 items (PCQ-12). The study involved 304 employees of different gender, age and position in an organization. Confirmatory factor analysis confirmed the existence of a common higher order factor that is superordinate and represents the four sub-dimensions. The internal reliability of the scale is satisfactory. A positive correlation between PsyCap, job and life satisfaction was also confirmed, and managers showed a higher level of PsyCap than employees. The results obtained indicate that the shortened version of the PsyCap questionnaire shows satisfactory reliability and validity.

Key words: psychological capital (PsyCap), self-efficacy, optimism, hope, psychological resiliency, psychometric validation, Psychological Capital Questionnaire with 12-items (PCQ-12) 